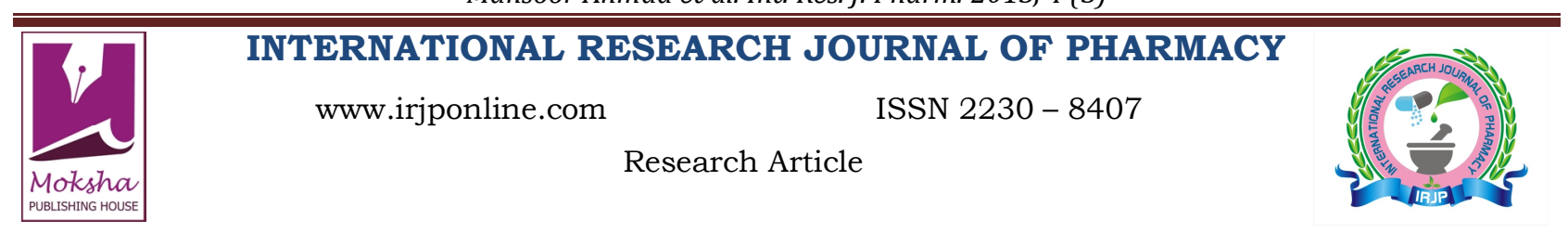

\title{
NOVEL INVESTIGATIONS ON THUJA OCCIDENTALIS EXTRACT ON RABBIT HEMATOLOGICAL AND BIOCHEMICAL PARAMETERS
}

Mansoor Ahmad ${ }^{1 *}$, Farah-Saeed ${ }^{2}$, Mehjabeen $^{3}$, Noor Jahan ${ }^{4}$, Syed Mahboob Alam ${ }^{5}$

${ }^{1}$ Research Institute of Pharmaceutical Sciences, Department of Pharmacognosy, University of Karachi, Pakistan

${ }^{2}$ Department of Pharmacognosy, Dow College of Pharmacy, Dow University of Health Sciences, Ojha Campus, Karachi, Pakistan

${ }^{3}$ Department of Pharmacology, Faculty of Pharmacy, Federal Urdu University, Karachi, Pakistan

${ }^{4}$ Department of Pharmacology, Dow College of Pharmacy, Dow University of Health Sciences, Ojha Campus, Karachi, Pakistan

${ }^{5}$ Department of Pharmacology and Therapeutics, BMSI, Jinnah Postgraduate Medical Center, Karachi, Pakistan

Email: mehjbn1@gmail.com

Article Received on: 10/01/13 Revised on: 01/02/13 Approved for publication: 13/03/13

DOI: $10.7897 / 2230-8407.04326$

IRJP is an official publication of Moksha Publishing House. Website: www.mokshaph.com

(C) All rights reserved.

\section{ABSTRACT}

Thuja occidentalis (family: Cupressaceae) has been used as antiseptic, expectorant, diuretic and in the treatment of cancer and removal of kidney stones in different systems of medicine. The present studies were carried out on $T$. occidentalis leaves extract to evaluate the hematological and biochemical effects on rabbits. The animals were divided in to control (A and B) and treated (C and D) male and female groups ( $\mathrm{n}=5$ ). There was a slight decrease in Hemoglobin, Red blood cell count and Hematocrit/Packed cell volume values, while a significant increase in platelet count was observed in male and female treated groups. However, slight increase in total leukocyte count value in male treated group and decrease count with female treated group was also observed. Urea, Creatine phospho kinase, Creatine phospho kinase iso-enzyme, Direct Bilirubin, Gamma-glutamyl transpeptidase, Cholesterol and Albumin/Globulin ratio values were elevated in male treated group. While Phosphorus, Uric acid, Lactate dehydrogenase, Serum glutamic oxaloacetic transaminase, serum glutamic-pyruvic transaminase, Alkaline Phosphatase, Cholesterol, Triglycerides, High density lipoprotein, Low density lipoprotein, Very-low-density lipoprotein, Globulin and Blood Glucose values were found low. In female treated group almost same results were observed like male treated group except that hypoglycemic effect was more pronounced in female treated group. These findings suggested that when results of hematological and biochemical parameters of test groups (C \& D) were compared with their respective controls (A \& B), significant changes were observed which contributes towards the diversified therapeutic effect of $T$. occidentalis.

Keywords: Thuja occidentalis, hematology, biochemical parameters

\section{INTRODUCTION}

The drugs derived from plant kingdom are being increasingly used along with conventional medicine to improve the general health and wellbeing of ailing humanity. Therefore, the level of research on the pre-clinical and clinical efficacy of herbal products needs to be enhanced ${ }^{1}$.

The evaluation of hematological and biochemical analysis of the blood helps in determining both the physiological and pathological conditions ${ }^{2}$. It also helps the researchers carrying out pre-clinical trial, to confirm diagnosis, estimate the severity of disease, give proper treatment, and evaluate outcomes. To interpret data correctly, the results obtained in the laboratory must be compared with values corresponding to the reference values of clinically healthy animals, which serve as a guideline to the clinician in evaluating parameters ${ }^{3}$. The impact of specie status, breed, sex, age, nutrition, illness, and seasonal variations, cannot be underestimated ${ }^{4}$.

Thuja occidentalis (Arbor vitae, yellow cedar) belongs to the family, Cupressaceae. The leaves of $T$. occidentalis contain volatile oil (with up to $60 \%$ thujone), flavonoids, wax, mucilage and tannins. The established medicinal uses are as anti-viral $^{5}$, expectorant and anti-catarrhal ${ }^{6}$, counter-irritant and diuretic. It is prescribed for both internal and external use in the treatment of warts and polyps as well as for treating amenorrhea $^{7-9}$. It is an intensively used medicinal plant in Pakistan, especially in homeopathic system of medicine ${ }^{8}$.

The present investigation was undertaken to assess the effect of the crude leaf extract of Thuja occidentalis on hematological and biochemical parameters in rabbits because there is no such information available in literature.

\section{MATERIAL AND METHOD}

T. occidentalis leaves were collected from the Botanical Garden of University of Karachi and identified by Prof. Dr. Mansoor Ahmad, Research Institute of Pharmaceutical Sciences, University of Karachi. A specimen voucher (FS01012011TO) of plant material is deposited in the herbarium of Department of Pharmacognosy, University of Karachi.

\section{Preparation of extract}

The collected fresh leaves $(5 \mathrm{~kg})$ of $T$. occidentalis were air dried at $25^{\circ} \mathrm{C}$ and were chopped into small pieces. The chopped material was soaked in $3 \mathrm{~L}$ ethanol. Alcoholic extract was prepared by percolation. This procedure was repeated thrice. Extract was concentrated by rota-evaporator (BuchiRotary Evaporator, Switzerland, model \# B490) at $40^{\circ} \mathrm{C}$. The yield of the extract was $450 \mathrm{gm}$.

\section{Animals}

Twenty rabbits of either sex (weighing between 1000 and $1200 \mathrm{~g})$ were purchased from animal house of Dow University of Health Sciences (DUHS) Karachi. They were kept in animal house for a period 15 days to acclimatize. They were fed commercial feed and water ad libitum. Their weights were checked on random basis.

\section{Treatments}

Four groups were made (n-5), group A (male control) group $\mathrm{B}$ (female control), group $\mathrm{C}$ (male treated) and group D (female treated). Group A and Group B received distil water, while Group C and D were administered $25 \mathrm{mg} / \mathrm{kg} T$. 
occidentalis. All the administrations were given orally at the interval of 24 hours for a period of 90 days. Blood was collected by cardiac puncture with $10 \mathrm{ml}$ sterile syringe using $1 \mathrm{mg} / 1 \mathrm{ml}$ EDTA as anticoagulant for the determination of blood and biochemical parameters as per requirement.

\section{Hematological Evaluation}

Total erythrocyte counts were counted using a Neubar chamber under a light microscope at $40 \times 10$ magnifications. Blood samples were diluted to 200 times by Hayem's reagent before counting. Blood hemoglobin concentration was determined using a Sahli's hemometer. Micro Wintrobe hematocrit tubes and hematocrit centrifuge were used to determine the PCV. Total leucocyte counts (TLC) were detected by using a Neubar chamber under a light microscope at $10 \times 10$ magnification after diluting blood samples to 10 times with Turk's solution. Mean erythrocyte volume, mean corpuscular hemoglobin $(\mathrm{MCH})$ and mean corpuscular hemoglobin concentration (MCHC) for particular blood samples were also calculated ${ }^{10-12}$.

\section{Biochemical Evaluation}

Serum samples were obtained by centrifugation of blood at $1300 \mathrm{x} \mathrm{g}$ for $15 \mathrm{~min}$. The Menarini Classic Chemistry Analyzer was used to determine the calcium $(\mathrm{Ca})$, phosphorus $(\mathrm{P})$, blood urea, creatinine, total bilirubin, total protein, albumin, alkaline phosphatase (ALP), aspartate aminotransferase (AST), alanine aminotransferase (ALT), creatine phosphokinase (CPK), cholesterol, glucose, amylase, and gamma-glutamyl transferase (GGT). The globulin concentration was determined by subtracting the albumin concentration from the total protein concentration ${ }^{13-14}$.

\section{Statistical Analysis}

Results of the study were presented as a mean plus or minus standard error of mean $(\mathrm{M} \pm \mathrm{SEM})$. Differences between control and treatment groups were analyzed by student ttest $^{15}$.

Table 1: Comparison of hematological parameters of group C compared with group A

\begin{tabular}{|c|c|c|}
\hline Rabbits Blood Samples & $\begin{array}{c}\text { Control (Male) [Group A] } \\
\text { Mean } \pm \text { SEM }\end{array}$ & $\begin{array}{c}\text { TM Thuja occidentalis (male) [Group C] } \\
\text { Mean } \pm \text { SEM }\end{array}$ \\
\hline Hb (g/dl) & $11.08 \pm 0.08586$ & $10.64 \pm 0.05098$ \\
\hline RBC count (million/ $\boldsymbol{\mu l}$ ) & $5.256 \pm 0.09033$ & $4.936 \pm 0.02727$ \\
\hline HCT/PCV (\%) & $39.380 \pm 0.28174$ & $36.2 \pm 0.2665$ \\
\hline MCV (fl) & $72.360 \pm 0.273$ & $73.36 \pm 0.2732$ \\
\hline MCH (pg) & $20.600 \pm 0.1672$ & $21.28 \pm 0.1498$ \\
\hline MCHC (g/dl) & $28.150 \pm 0.124$ & $29.06 \pm 0.05098$ \\
\hline TLC (/L) & $8.760 \pm 0.051$ & $10.1 \pm 0.1185$ \\
\hline Platelet count (/L) & $619.000 \pm 1.000$ & $431.8 \pm 1.0674$ \\
\hline
\end{tabular}

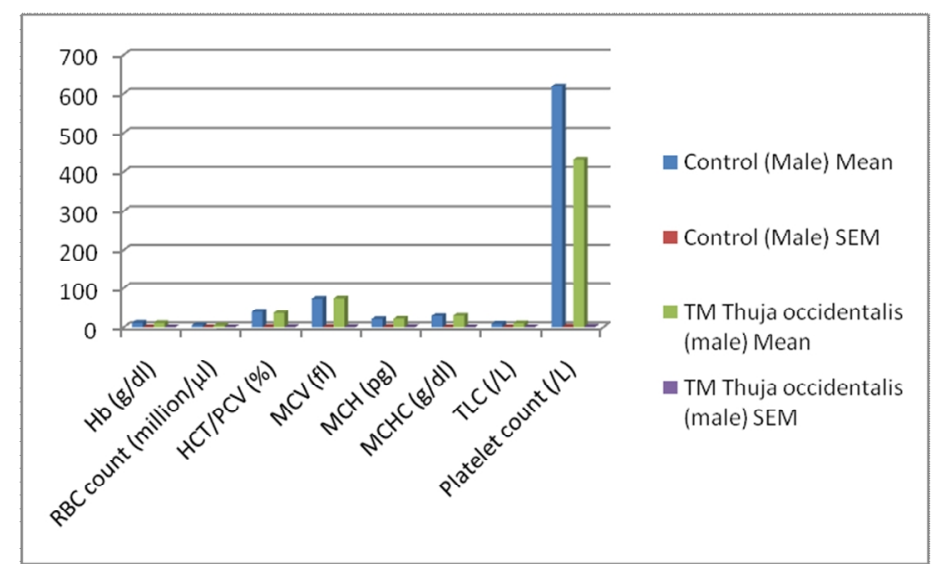

Graph 1: Comparison of hematological parameters of group C compared with group A

Table 2: Comparison of hematological parameters of group D compared with group B

\begin{tabular}{|c|c|c|}
\hline Rabbits Blood Samples & $\begin{array}{c}\text { Control (Female) [Group B] } \\
\text { Mean } \pm \text { SEM }\end{array}$ & $\begin{array}{c}\text { TF Thuja occidentalis (female) [Group D] } \\
\text { Mean } \pm \text { SEM }\end{array}$ \\
\hline Hb (g/dl) & $12.18 \pm 0.1068$ & $10.34 \pm 0.1077$ \\
\hline RBC count (million/ $\boldsymbol{\mu l})$ & $5.766 \pm 0.0778$ & $5.088 \pm 0.03309$ \\
\hline HCT/PCV (\%) & $42.600 \pm 0.1703$ & $36.16 \pm 0.1207$ \\
\hline MCV (fl) & $72.040 \pm 0.144$ & $70.96 \pm 0.2598$ \\
\hline MCH (pg) & $20.680 \pm 0.080$ & $20.42 \pm 0.1426$ \\
\hline MCHC (g/dl) & $28.160 \pm 0.108$ & $7.18 \pm 0.1158$ \\
\hline TLC (/L) & $8.780 \pm 0.086$ & $325.8 \pm 1.685$ \\
\hline Platelet count (/L) & $619.400 \pm 1.631$ & \\
\hline
\end{tabular}




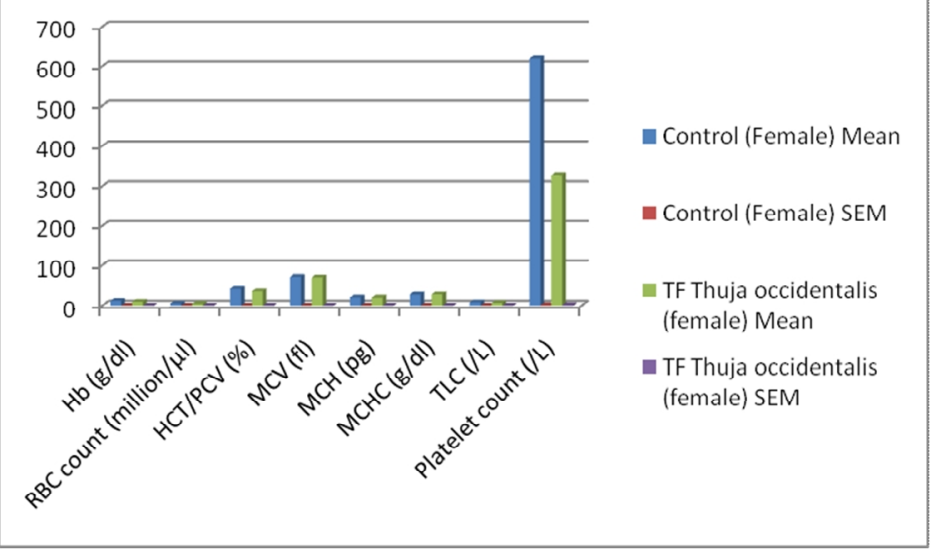

Graph 2: Comparison of hematological parameters of group D compared with group B

Table 3: Comparison of biochemical parameters of group C compared with group A

\begin{tabular}{|c|c|c|}
\hline Biochemical Parameters & $\begin{array}{c}\text { Control (Male) [Group A] } \\
\text { Mean } \pm \text { SEM }\end{array}$ & $\begin{array}{c}\text { Test Animal (TM) [Group C] } \\
\text { Mean } \pm \text { SEM }\end{array}$ \\
\hline Urea & $21.8 \pm 0.9695$ & $30.1 \pm 0.6404$ \\
\hline Creatinine & $0.85 \pm 0.01609$ & $0.826 \pm 0.00939$ \\
\hline Calcium (serum) & $14.144 \pm 0.04337$ & $14.734 \pm 0.08228$ \\
\hline Phosphorus & $6.148 \pm 0.04427$ & $3.862 \pm 0.07021$ \\
\hline Uric acid & $0.156 \pm 0.01609$ & $0.048 \pm 0.00849$ \\
\hline LDH & $270.6 \pm 1.0768$ & $101.12 \pm 1.09297$ \\
\hline CPK & $422.6 \pm 1.7776$ & $525 \pm 1.8438$ \\
\hline CK-MB & $194.4 \pm 1.3639$ & $626.8 \pm 1.0196$ \\
\hline SGOT & $42.8 \pm 1.6551$ & $21.6 \pm 1.20835$ \\
\hline Total Bilirubin & $0.266 \pm 0.01073$ & $0.258 \pm 0.016993$ \\
\hline Direct Bilirubin & $0.03 \pm 0.00715$ & $0.082 \pm 0.01296$ \\
\hline SGPT & $67.4 \pm 0.8716$ & $51.4 \pm 1.20835$ \\
\hline Alkaline Phosphatase & $229 \pm 1.7029$ & $33.6 \pm 1.20835$ \\
\hline Gamma GT & $8 \pm 0.70703$ & $11.4 \pm 1.0294$ \\
\hline Total lipids & $199.4 \pm 1.6309$ & $198 \pm 0.70703$ \\
\hline Cholesterol & $58.8 \pm 1.15737$ & $21.6 \pm 1.20835$ \\
\hline Triglycerides & $131.4 \pm 1.2083$ & $97.6 \pm 0.9275$ \\
\hline HDL & $7.2 \pm 0.8604$ & $3 \pm 0.70703$ \\
\hline LDL & $39 \pm 0.9999$ & $7.2 \pm 0.8604$ \\
\hline VLDL & $28.2 \pm 1.2808$ & $19 \pm 0.99995$ \\
\hline Total proteins & $7.478 \pm 0.02504$ & $7.326 \pm 0.02504$ \\
\hline Albumin & $4.316 \pm 0.02638$ & $4.946 \pm 0.05008$ \\
\hline Globulin & $3.178 \pm 0.02504$ & $2.4 \pm 0.035329$ \\
\hline A/G ratio & $1.35 \pm 0.05008$ & $2.052 \pm 0.01788$ \\
\hline Blood Glucose & $132.8 \pm 1.3926$ & $127.2 \pm 0.8604$ \\
\hline & & \\
\hline
\end{tabular}

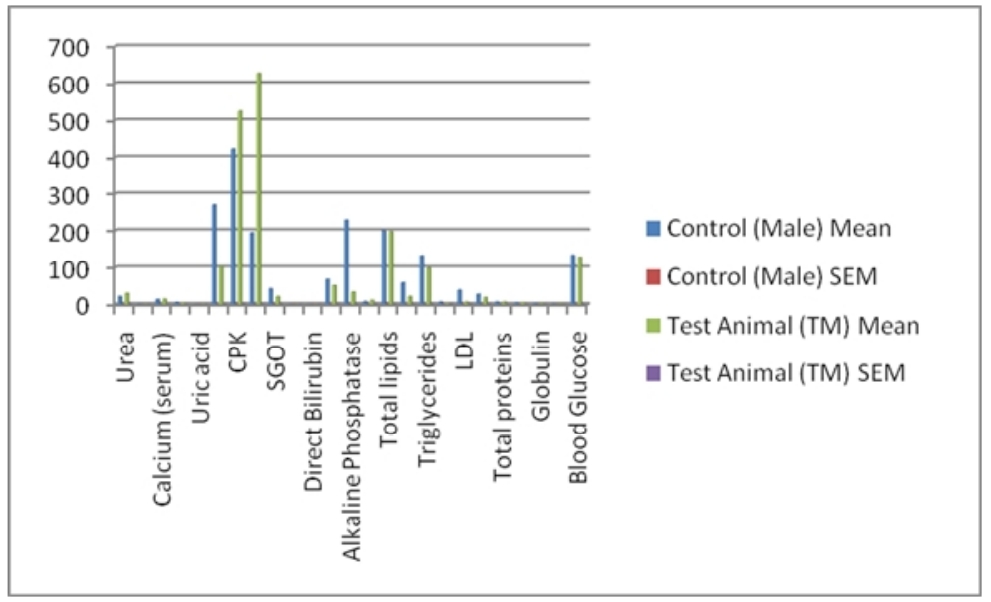

Graph 3: Comparison of biochemical parameters of group C compared with group A 
Mansoor Ahmad et al. Int. Res. J. Pharm. 2013, 4 (3)

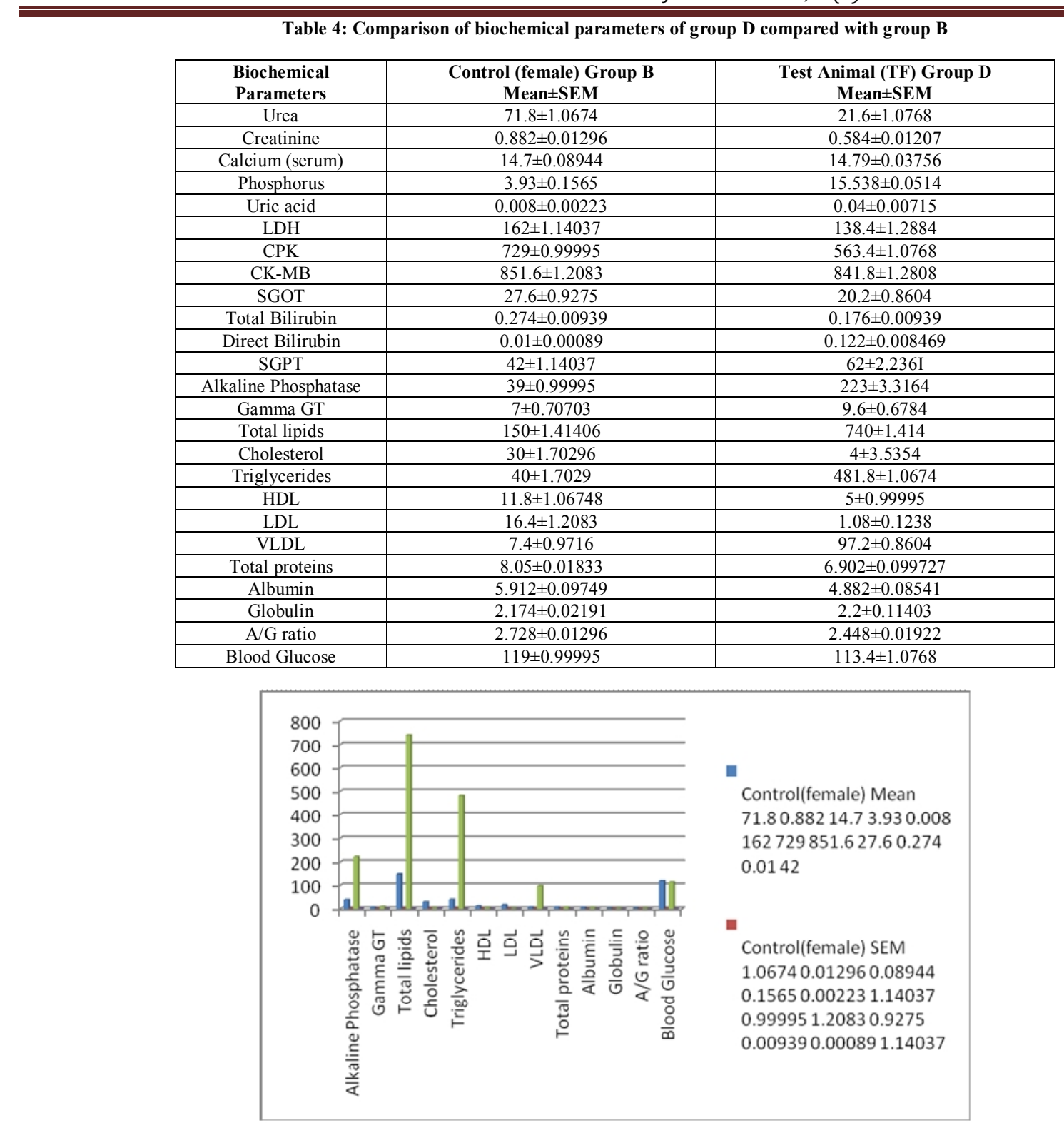

Graph 4: Comparison of biochemical parameters of group D compared with group B

\section{RESULTS}

\section{Hematology}

The results of group $\mathrm{C}$ in comparison with group $\mathrm{A}$, showed slight decrease in hemoglobin, RBC count, HCT/PCV and increased TLC count. The platelet count was significantly decreased in group $\mathrm{C}$ (Table 1). The slight decrease in hemoglobin, RBC count, HCT/PCV and TLC values were observed in group $\mathrm{D}$, while significant decrease in platelet count was also noted (Table 2).

\section{Biochemistry}

Increased urea and decreased uric acid and phosphorus levels were observed in group C (Table 3). In group D (compared with group B), decreased values of urea, creatinine and increased uric acid were noted. However, phosphorus content in blood was significantly increased (Table 4).

In group $\mathrm{C}$ and $\mathrm{D}$, elevated $\mathrm{CPK}$ and $\mathrm{CK}-\mathrm{MB}$ and lowered SGOT level (Table 3) and decreased in LDH, CPK, SGOT and CK-MB values were observed respectively (Table 4).

Increased Gamma GT and direct bilirubin values while decreased SGPT and alkaline phosphatase were observed in group C (Table 3). In contrast the results of group D showed decreased total bilirubin, while increased direct bilirubin, SGPT, alkaline phosphatase, and Gamma GT levels (Table 4).

Similarly for lipid profile the results of group $\mathrm{C}$ exhibited decrease cholesterol, triglycerides, HDL, LDL and VLDL levels (hypolipidemic effect) (Table 3). Group D also showed decreased cholesterol, HDL and LDL where as total lipid and triglycerides levels were significantly elevated (Table 4).

\section{DISCUSSION}

T. occidentalis has history of strong medicinal use. In Europe, it was used for the cure of warts ${ }^{8}$. Chemically it has many chemical compounds, such as, $\mathrm{d}-\alpha$-pinene, $\mathrm{d}-\alpha$-thujone, 1-fenchone, 1-borneal, acetic-, formic-, and iso-valeric acids, terpineol, sabinene, camphene, camphor, valerianic acid, occidol, $\beta$ sitosterol, quercitrin, rhodoxanthine, $5.9 \%$ tannins, resins, mucilage and vitamin $\mathrm{C}{ }^{16}$. Northern white-cedar browse is, on average by wet weight, $5.2 \%$ fat, $2.7 \%$ protein, $13.9 \%$ crude fiber, $27.5 \%$ carbohydrates and high in 
calcium $^{17}$. Our previous chemical investigation also confirms the presence of similar compounds ${ }^{9}$.

Literature revealed that $T$.occidentalis has been used by human beings since more than 200 years. Therefore, to determine its therapeutic effects we carried out the research on different blood parameters in model experiments (rabbits in vivo) included blood chemistry, cardiac enzymes, liver enzymes and lipid profile. Interesting results were obtained which showed the drug has powerful affinity and efficacy for the treatment of many diseases.
In both treated groups $\mathrm{C}$ and $\mathrm{D}$, there was slight decrease in hemoglobin, RBC count, and $\mathrm{HCT} / \mathrm{PCV}$ values. In male treated group there was slight increase in TLC while in female treated group TLC value has become low. Significant lowering of platelets count was also observed in both treated groups and showed the anti-platelet effect [Table A \& B]. Several researchers find out that pure valerianic acid reduces the platelet count and T. occidentalis extract contain this property ${ }^{18}$.

Table A: Hematology parameters of group C (male treated) compared with group A (male control)

\begin{tabular}{|c|c|c|c|c|c|c|c|}
\hline $\begin{array}{c}\mathrm{Hb} \\
(\mathrm{g} / \mathrm{dl})\end{array}$ & $\begin{array}{c}\text { RBC count } \\
(\mathrm{million} / \mu \mathrm{l})\end{array}$ & $\begin{array}{c}\mathrm{HCT} / \mathrm{PCV} \\
(\%)\end{array}$ & $\begin{array}{c}\mathrm{MCV} \\
(\mathrm{fl})\end{array}$ & $\begin{array}{c}\mathrm{MCH} \\
\mathrm{pg})\end{array}$ & $\begin{array}{c}\mathrm{MCHC} \\
(\mathrm{g} / \mathrm{dl})\end{array}$ & $\begin{array}{c}\text { TLC } \\
(/ \mathrm{L})\end{array}$ & $\begin{array}{c}\text { Platelet count } \\
(/ \mathrm{L})\end{array}$ \\
\hline & 4 & 4 & 1 & 1 & 1 & 4 & 5 \\
\hline
\end{tabular}

Table B: Hematology parameters of group D (female treated) compared with group B (female control)

\begin{tabular}{rl|c|c|c|c|c|c|c|}
\hline $\begin{array}{c}\mathrm{Hb} \\
(\mathrm{g} / \mathrm{dl})\end{array}$ & $\begin{array}{c}\text { RBC count } \\
(\mathrm{million} / \mu \mathrm{l})\end{array}$ & $\begin{array}{c}\text { HCT/PCV } \\
(\%)\end{array}$ & $\begin{array}{c}\text { MCV } \\
(\mathrm{fl})\end{array}$ & $\begin{array}{c}\mathrm{MCH} \\
(\mathrm{pg})\end{array}$ & $\begin{array}{c}\text { MCHC } \\
(\mathrm{g} / \mathrm{dl})\end{array}$ & $\begin{array}{c}\text { TLC } \\
(/ \mathrm{L})\end{array}$ & $\begin{array}{c}\text { Platelet count } \\
(/ \mathrm{L})\end{array}$ \\
\hline & 4 & 4 & 1 & 1 & 1 & 2 & 5 \\
\hline
\end{tabular}

Table C: Biochemical parameters of group C (male test) compared with group A (male control)

\begin{tabular}{|c|c|c|c|c|c|c|c|c|c|c|c|c|c|c|c|c|c|c|c|c|c|c|c|c|}
\hline$\stackrel{\Xi}{\Xi}$ & 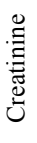 & 泀 & $\frac{2}{2}$ & 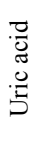 & $\stackrel{\mathbb{I}}{9}$ & $\frac{v}{0}$ & 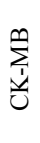 & $\begin{array}{l}5 \\
0 \\
\text { ర }\end{array}$ & 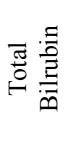 & 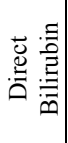 & 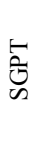 & 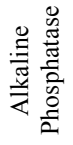 & 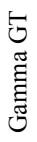 & 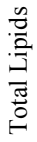 & $\begin{array}{l}\overline{0} \\
\frac{0}{0} \\
\frac{0}{0} \\
\frac{0}{0} \\
\text { U. }\end{array}$ & 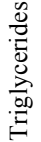 & 主 & $\vec{a}$ & $\stackrel{\overrightarrow{9}}{\overrightarrow{3}}$ & 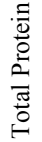 & $\begin{array}{l}\Xi \\
\Xi \\
\vdots \\
\vdots\end{array}$ & $\begin{array}{l}: \Xi \\
\frac{0}{0} \\
\frac{0}{0}\end{array}$ & 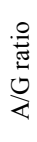 & 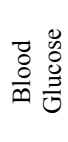 \\
\hline 2 & 1 & 1 & 4 & 4 & 1 & 2 & 3 & 5 & 1 & 2 & 4 & 5 & 2 & 1 & 5 & 4 & 4 & 5 & 4 & 1 & 1 & 4 & 3 & 4 \\
\hline
\end{tabular}

Table D: Biochemical parameters of group D (female test) compared with group B (female control)

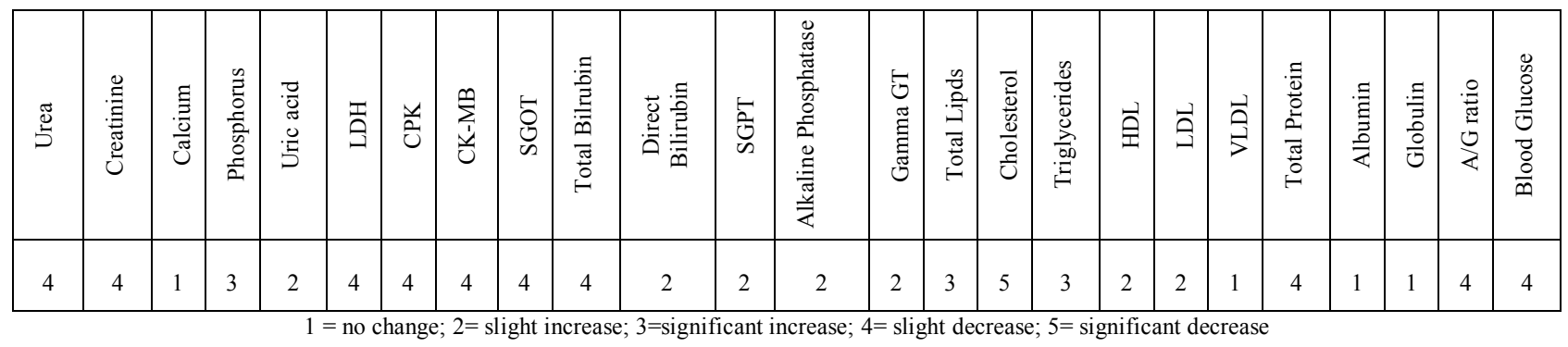

In this study LDH, CPK and SGOT were reduced from normal values in comparison to control. Borneol, camphor, $\beta$ sitosterol, vitamin $\mathrm{C}$, and calcium having the properties to reduce $\mathrm{LDH}, \mathrm{CPK}$ and SGOT and maintain tone of heart, improves circulation and protect from coronary heart disease (CHD). These chemical compounds are reported from T.occidentalis plant.

Increase in direct bilirubin and negligible changes in total bilirubin were observed. This may be because of the presence of quercitrin (a flavonoid) in $T$. occidentalis extract. $T$. occidentalis extract produces hypolipidemic effect by decreasing cholesterol, LDL, HDL. It is quite interesting to note that $T$. occidentalis extract have crude fibers, $\beta$-sitosterol and vitamin $\mathrm{C}$ which prevent clotting in veins and arteries, heart attack, stroke, high blood pressure and high cholesterol. Therefore, such action also supported the hypolipidemic effect of this extract ${ }^{5,19,20}$.
T. occidentalis, found to decrease the creatinine and urea in female treated group and slight increased values were observed in male treated group. This kind of action is reported by the presence of tannins and $\alpha$-pinene. Uric acid was decreased in male treated group. Since the extract of $T$. occidentalis maintain the blood parameters within control limits so it can be use as an immuno-stimulant, antimicrobial, anti-viral, antioxidant and blood purifier agent. More over T. occidentalis also facilitates its utilization for the treatment of upper respiratory tract infections ${ }^{5,}{ }^{6}$.Other reported effects of $T$. occcidentalis were uterine stimulant, emmenagogue and aphrodisiac which may be due to the presence of $\beta$-sitosterol, Borneol, $\alpha$-thujone and crude fibers $^{22}$.

From this study it is suggested that therapeutic efficacy of Thuja occidentalis is the reflection of maintenance of complete blood count, decrease in platelet count, decrease in cardiac enzymes, increase in direct bilirubin, decrease in 
HDL and LDL levels, maintenance of the total proteins and decrease in blood glucose levels.

\section{CONCLUSION}

On the basis of previous and present results it can be concluded that T.occidentalis has diversified therapeutic effect and is beneficial in the treatment of various pathophysiological conditions associated with cancers, kidneys, skin, respiratory tract and digestive system.

\section{ACKNOWLEDGEMENT}

The authors are thankful to the University of Karachi for financial support, University of Karachi (PCMD Diagnostic Laboratories).

\section{REFERENCES}

1. Benzie IFF, Wachtel-Galor S (2011). Herbal Medicine: Biomolecular and Clinical Aspects. 2nd edition. CRC Press.

2. Coles, E.H (1986). Veterinary Clinical Pathology 4th Edition. W.B. Saunders Co. Philadelphia.

3. Yokus, B., Cakir, D.U., Kanay, Z., Gulten, T., Uysal, E (2006). Effects of seasonal and physiological variations on the serum chemistry, vitamins and thyroid hormone concentrations in sheep. J. Vet. Med. A Physiol. Pathol. Clin. Med.53: 271-276. http://dx.doi.org/ 10.1111/i.1439-0442.2006.00831.x PMid:16901267

4. Swanson, K.S., Kuzmuk, K.N., Schook, L.B., Fahey, G.C. Jr (2004) Diet affects nutrient digestibility, hematology, and serum chemistry of senior and weanling dogs. J. Anim. Sci. 82: 1713-1724. PMid:15216999

5. Challem, J; Taylor, EW (1998). Retroviruses, Ascorbate, and Mutations, in the Evolution of Homo sapiens. Free Radical Biology and Medicine. 25 (1): 130-2. http://dx.doi.org/10.1016/S08915849(98)00034-3

6. Naser B, Bodinet C, Tegtmeier M, Lindquist U (2005). Thuja occidentalis (Arbor vitae): A Review of its Pharmaceutical, Pharmacological and Clinical Properties. Evid Based Complement Alternat Med. 2(1):67-78. http://dx.doi.org/10.1093/ecam/neh065 PMid:15841280 PMCid:1062158

7. Sammbamurty, A.V.S.S (2006). Dictionary of Medicinal Plants.289 pp.

8. Alam SM (2009). Investigation on the different malignancies curing properties of herbal homeopathic drugs, Thuja occidentalis, Taraxacum officinale, Chelidonium majus, Cistus canadensis, etc. Ph.D. Thesis, Department of Pharmacognosy, University of Karachi, Pakistan
9. Jahan N, Ahmad M, Mehjabeen, Rehman A.B (2006). Screening of anti-microbial activity in chemotherapeutic agents, Terminalia arjuna,Tephrosia purpurea and Thuja occidentalis. Physio and Pharmacol, Supplement. 1:40.

10. Burnett N., Mathura K., Metivier K.S., Holder R.B., Brown G., Campbell M (2006). An investigation into hematological and serum chemistry parameters of rabbits in Trinidad. World Rabbit Sci., 14: $175-187$.

11. Dacie, J. V. and Lewis, S. M (1991). Practical Haematology. Churchill Livingstone. Edinburgh. Seventh edition.Pp. 521-534.

12. McGowen, J.J., Jones, A.A.R. and Steinerg, A.G (1955). The haematocrit of carpillary blood. New England J. Med. 253-308.

13. Amadori M., Archetti I.L., Frasnelli M., Bagni M., Olzi E., Caronna G., Lanteri M. (1997). An immunological approach to the evalutation of welfare in holstein frisian cattle. J. Vet. Med., 44, 321-327. http://dx.doi.org/10.1111/j.1439-0450.1997.tb00982.x

14. Reitman, S. and Frankel, A.S (1957). A colorimetric method of determination of serum glutamic oxaloacetic and glutamic pyruvic transaminases. Am. J. Clin. Pathol. 28:53- 63.

15. Snedecor GW \& Cochran WG (1967). Statistical Methods. Sixth edition. Ames, Iowa: The Iowa State University Press, pp 423.

16. List, P.H. \& Horhammer, L (1969-1971). Hager's handbuch der pharmazeutischen praxis vols 2-6. Springer-Verlag, Berlin.

17. Kudish \& Michael (1992). Adirondack upland flora: an ecological perspective. Saranac, NY: The Chauncy Press.320p.

18. Ellingwood F (1983). American Materia Medica, Therapeutics \& Pharmacognosy. Portland, Oregon: Electric Medical Publications. PMid:6406403

19. Richter, G. H (1945). Textbook of Organic Chemistry, 2nd ed., John Wiley \& S.

20. Proctor P (1970). "Similar functions of uric acid and ascorbate in man?" Nature.228 (5274): 868. http://dx.doi.org/10.1038/228868a0 PMid:5477017

21. Dean, W (1998). Benign Prostatic Hypertrophy, Near-Universal Malady in Men over 50. Vitamin Research News.

22. Anderson JW, Baird P, Davis RH Jr, Ferreri S, Knudtson M, Koraym A, Waters V, Williams CL. (2009). "Health benefits of dietary fiber". Nutr Rev.; 67 (4): 188-205. http://dx.doi.org/10.1111/j.17534887.2009.00189.x PMid: 19335713

Cite this article as:

Mansoor Ahmad, Farah-Saeed, Mehjabeen, Noor Jahan, Syed Mahboob Alam. Novel investigations on Thuja occidentalis extract on rabbit hematological and biochemical parameters. Int. Res. J. Pharm. 2013; 4(3):135-140 